\title{
Analisis Deskriptif Kematian Neonatal Di Rumah Sakit X Kabupaten Kediri Pada Tahun 2018
}

\author{
Eva Firdayanti Bisono ${ }^{1}$, Krisnita Dwi Jayanti ${ }^{2}$, Ekawati Wasis Wijayati ${ }^{3}$, Sevi Oktrianadewi ${ }^{4}$, Budi \\ Pranoto ${ }^{5}$ \\ Institut IImu Kesehatan Bhakti Wiyata Kediri ${ }^{12345}$ \\ eva.firdayanti@iik.ac.id
}

\begin{abstract}
Health efforts are made to control the risk of death it like keep delivery can be carried out by health workers at the health facilities and ensure health care service standars on a visit of a newborn infant. The purpose of this research is to find visions of death neonatal in the hospital $x$ ditrict Kediri. Research methodology descriptive and use this approach retrospective. The result of this research the number of infant mortality in 2018 as much as 185 death, with many infant mortality male sex as much as 110, and the time of death most less is more than equal to 48 hours 102 cases as many, infant mortality was greatest in October and December, the type of insurance used most BPJS as many as 86 and disesase cause of death most were low birth weight (LBW) as much as 93 cases. This is infant mortality rate which is 67,79 per 1000 live births. Should value the infant mortality reate can always do be done to a base in the plan for the hospital in providing some facilities can make mothers and children visited hospital especially full attention in October and December.
\end{abstract}

Keywords: Newborn infant, hospital, health efforts

\begin{abstract}
Abstrak: Upaya kesehatan yang dapat dilakukan untuk mengendalikan risiko kematian neonatus diantaranya dengan mengupayakan agar persalinan dapat dilakukan oleh tenaga kesehatan di fasilitas kesehatan serta menjamin tersedianya pelayanan kesehatan sesuai dengan standar pada kunjungan bayi baru lahir. Tujuan penelitian ini adalah untuk mengetahui gambaran kematian neonatal di RS X Kabupaten Kediri. Metode penelitian ini dengan deskriptif dan menggunakan pendekatan retrospetif. Hasil penelitian ini jumlah kematian bayi tahun 2018 sebanyak 185 kematian, dengan banyak kematian bayi berjenis kelamin laki laki sebesar 110, dan waktu kematian terbanyak $\leq 48$ Jam sebanyak 102 kasus, kematian bayi paling banyak terjadi pada bulan Oktober dan Desember, jenis jaminan kesehatan yang digunakan paling banyak BPJS sebanyak 86 dan penyakit penyebab kematian terbanyak adalah Bayi Berat Lahir Rendah (BBLR) sebanyak 93 kasus. Hasil perhitungan Angka Kematian Bayi yaitu sebesar 67,79 per 1000 kelahiran hidup. Sebaiknya nilai Angka Kematian Bayi dapat selalu dilakukan untuk dasar dalam membuat perencanaan bagi rumah sakit dalam menyediakan sarana dan prasarana yang dapat mendukung kesehatan ibu dan anak yang melakukan kunjungan ke rumah sakit utamanya perhatian penuh pada bulan Oktober dan Desember.
\end{abstract}

Kata Kunci: kematian neonatus, rumah sakit, upaya kesehatan 


\begin{tabular}{llll}
\hline Article History : & Received: 16-06-2021 & Revised: 24-06-2021 & Accepted: 25-06-2021 \\
\hline
\end{tabular}

\section{Pendahuluan}

Menurut Peraturan Pemerintah Republik Indonesia No 87 tahun 2014 tentang perkembangan kependudukan dan pembangunan keluarga, keluarga berencana dan sistem informasi keluarga, keluarga memiliki peran dalam mengoptimalisasi pertumbuhan,perkembangan dan produktivitas seluruh anggota keluarga melalui pemenuhan kebutuhan gizi serta dapat menjamin kesehatan anggota keluarga. ${ }^{1}$ Komponen anggota keluarga terdapat ibu dan anak yang merupakan kelompok rentan. Kelompok rentan ini terkait dengan pada ibu ada fase kehamilan, persalinan dan nifas, sedangkan pada anak terdapat fase tumbuh kembang, hal ini yang menjadi dasar pentingnya meningkatkan upaya kesehatan ibu dan anak yang menjadi salah satu prioritas pembangunan kesehatan di Indonesia. Sehingga penilaian terhadap status kesehatan dan kinerja upaya kesehatan ibu dan anak menjadi penting untuk dilakukan. ${ }^{2}$

Upaya pemeliharaan kesehatan anak dilakukan sejak janin masih dalam kandungan, dilahirkan, dan setelah dilahirkan sampai berusia 18 tahun. Neonatus merupakan bayi baru lahir sampai dengan usia 28 hari,pada usia tersebut merupakan golongan umur yang memiliki risiko ganguan kesehatan paling tinggi, sehingga tanpa penanganan yang tepat, bisa berakibat fatal. Upaya kesehatan yang dapat dilakukan untuk mengendalikan risiko kematian neonatus diantaranya dengan mengupayakan agar persalinan dapat dilaukan oleh tenaga kesehatan di fasilitas kesehatan serta menjamin tersedianya pelayanan kesehatan sesuai dengan standar pada kunjungan bayi baru lahir ${ }^{3}$

Statistik kematian atau statistik mortalitas di Rumah Sakit merupakan proporsi dari jumlah pasien rawat inap yang meninggal dan yang masih dalam perawatan. Statistik kematian ini sangat penting untuk menunjukkan hasil evaluasi bagaimana kualitas pelayanan medis di Rumah Sakit ${ }^{4}$ salah satu ukuran kematian yang digunakan adalah Infant Mortality Ratio atau Angka Kematian Bayi (AKB) usia 0-11 bulan. Diperkirakan setiap tahunnya sekitar 4 juta bayi meninggal pada tahun pertama kehidupannya dan dua pertiganya meninggal pada bulan pertama ${ }^{5}$. Target Renstra kementerian kesehatan pada

\footnotetext{
${ }^{1}$ PP No. 87, "Peraturan Pemerintah Republik Indonesia Nomor 87 Tahun 2014 Tentang Perkembangan Kependudukan Dan Pembangunan Keluarga, Keluarga Berencana, Dan Sistem Informasi Keluarga," Salinan (2014): 1-65.

${ }^{2}$ profil kesehatan indonesia, Provil Kesehatan Indonesia 2018, vol. 1227, 2018, website: http://www.kemkes.go.id.

${ }^{3}$ Ibid.

${ }^{4}$ Rano Indradi Sudra, Statistik Rumah Sakit (KAB. SLEMAN - SLEMAN, DI YOGYAKARTA, ID: Graha IImu, 2010).

${ }^{5}$ Dinas Kesehatan Kab. Kediri Pemerintah Kabupaten Kediri, “Profil Kesehatan Kabupaten Kediri Tahun 2016" (2016).
}

Copyright@ 2020; MASOKAN, ISSN: $\quad$ (print), $\quad$ (online) $\mid 42$ 
tahun 2019 untuk AKB adalah 24 per $1000 \mathrm{KH}$, sedangkan target MDG's adalah 23 per $1000 \mathrm{KH}$ pada tahun 2015. Berdasarkan Hasil Survei Demografi dan Kesehatan Indonesia (SDKI) tahun 2017 AKB menunjukkan penurunan sebesar 24 per $1.000 \mathrm{KH}^{6}$, dibandingkan tahun 2012 lalu sebesar 32 per $1.000 \mathrm{KH}$. Angka Kematian Bayi di Kabupaten Kediri pada tahun 2017 sebesar 6,33 per 1.000 KH, dengan kematian sebanyak 155 kasus, angka ini menurun bila dibandingkan dengan tahun 2015 sebesar 7,6 per $1.000 \mathrm{KH}^{7}$. Berdasarkan latar belakang tersebut, peneliti tertarik untuk mengetahui bagaimana gambaran atau mendeskripsikan kematian neonatal di RS X Kabupaten Kediri.

\section{Metode Penelitian}

Jenis penelitian yang digunakan adalah deskriptif dengan dilakukan terhadap sekumpulan obyek yang biasanya bertujuan untuk mengetahui gambaran fenomena (termasuk kesehatan) yang terjadi didalam suatu populasi tertentu ${ }^{8}$. Pendekatan dalam penelitian ini adalah Studi Retrospektif (Retrospective Study), pendekatan ini merupakan penelitian yang berusaha melihat ke belakang (backwards looking), dimana artinya pengumpulan data dilakukan dari efek atau akibat yang telah terjadi, kemudian dari efek tersebut diteruskan kebelakang untuk mengatahui penyebabnya atau variabel-variabel yang mempengaruhi akibat tersebut. ${ }^{9}$ Data dalam penelitian ini diperoleh dari data rekam medis kematian bayi baru lahir.

\section{Hasil dan Pembahasan}

Hasil penelitian dapat diketahui bahwa jumlah kunjungan bayi beserta kematian bayi yang keluar rawat inap di RS X Kabupaten Kediri, diperoleh dari rekapan Register Pasien Rawat Inap yang digolongkan berdasarkan usia (0 hari sampai kurang dari 1 tahun), untuk mengetahui jumlah kunjungan bayi tahun 2018 dapat dilihat pada tabel berikut:

Tabel1 Rekapitulasi Tahunan Kunjungan Bayi Tahun 2014-2018 di RS X Kabupaten Kediri.

\begin{tabular}{ccccc}
\hline & Jumlah Bayi & \multicolumn{2}{c}{ Jumlah Bayi mati } & Total Bayi \\
Tahun & Hidup (M) & \multicolumn{2}{c}{ Jumlah (M+N) } & Mati (N)
\end{tabular}

${ }^{6}$ Badan Pusat Statistik et al., "Survei Demografi Dan Kesehatan Indonesia 2012," Sdki (2013): 16.

${ }^{7}$ Dinas Kesehatan Kab. Kediri Pemerintah Kabupaten Kediri, "Profil Dinas Kesehatan Kabupaten Kediri" (2017).

${ }^{8}$ Soekidjo Notoatmodjo, Metodologi Penelitian Kesehatan (KOTA SURABAYA - BUBUTAN, JAWA TIMUR, ID: Rineka Cipta, 2018).

${ }^{9}$ Ibid. 


\begin{tabular}{rrrrrr}
\hline $\mathbf{2 0 1 8}$ & 2.729 & 102 & 83 & 185 & 2.914 \\
\hline TOTAL & 2.729 & 102 & 83 & 185 & 2.914 \\
\hline
\end{tabular}

Tabel 1 diketahui Kunjungan bayi di RS X Kabupaten Kediri pada tahun 2018 adalah 2.914 kunjungan bayi. Jumlah kematian bayi $\leq 48$ Jam lebih besar dibanding dengan kematian $\geq 48$ Jam, untuk lebih jelasnya, angka kematian berdasarkan waktu dapat dilihat pada gambar 1 .

Kematian bayi per bulan paling banyak terjadi pada bulan Oktober dan Desember sebanyak 27 kematian dan dari gambar tersebut dapat diketahui bahwa yang paling banyak waktu kematian bayi adalah $\leq 48$ Jam hampir di semua bulan selama tahun 2018. Kematian bayi kurang dari 48 jam tertinggi terjadi pada bulan Januari dan Desember tahun 2018 sebanyak 14 kematian bayi, sedangkan terendah terdapat pada bulan Juli sebanyak 3 kematian bayi. Kemudian kematian lebih dari 48 jam, jumlah tertinggi terdapat pada bulan Oktober 2018 sebanyak 14 kematian bayi, sedangkan jumlah terendah terdapat pada Mei sebanyak 1 kematian bayi.

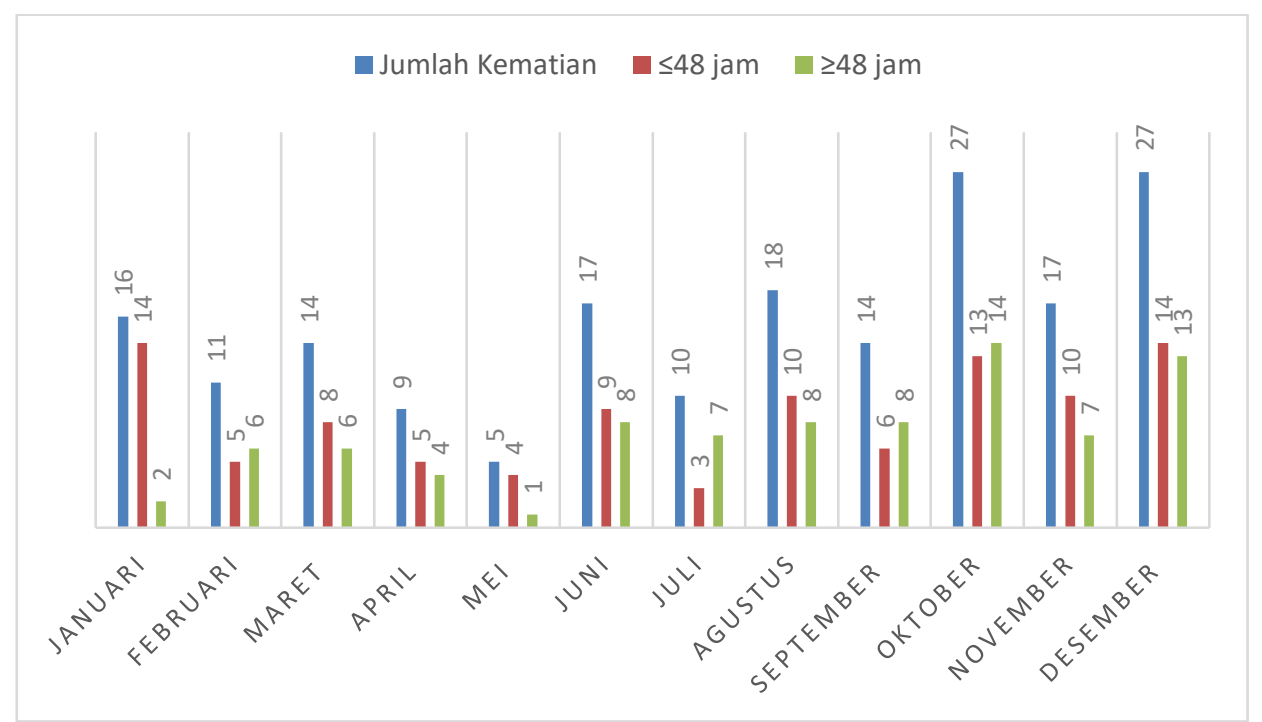

Gambar 1. Rekap Per Bulan Kematian Bayi Berdasarkan Waktu Tahun 2018

Berdasarkan Gambar 2 dapat diketahui bahwa kematian bayi banyak terjadi pada usia 0-6 hari sebanyak 182 bayi meninggal yang berarti adalah bayi baru lahir atau neonatus, dan pada usia 7-28 hari sebanyak 3 bayi. Kematian bayi usia 0-6 hari tertinggi terjadi pada bulan Oktober dan Desember tahun 2018 sebanyak 27 kematian bayi, sedangkan terendah terdapat pada bulan Mei sebanyak 5 kematian bayi. Kemudian kematian bayi usia 7-28 hari jumlah tertinggi terdapat pada bulan Juni 2018 sebanyak 3 kematian bayi. Tingkat kematian bayi di Indonesia masih tergolong tinggi jika 
dibandingkan dengan negara negara ASEAN yaitu 4,6 kali lebih tinggi dari Malaysia, 1,3 kali lebih tinggi dari Filipina dan 1,8 kali lebih tinggi dari Thailand. Tingginya kematian anak pada usia hingga satu tahun yaitu sepertiganya terjadi dalam satu bulan pertama setelah kelahiran dan sekitar 80 persen kematian neonatal ini terjadi pada minggu pertama menunjukkan bahwa masih rendanya status kesehatan ibu dan bayi baru lahir, rendahnya akses dan kualitas pelayanan kesehatan ibu dan anak khususnya pada masa persalinan dan segera sesudahnya. Selain itu perilaku baik secara preventif dan kuratif bagi ibu hamil dan keluarga serta masyarakat yang bersifat negatif pada perkembangan kesehatan kehamilan, persalinan yang aman dan perkembangan dini pada anak. ${ }^{10}$

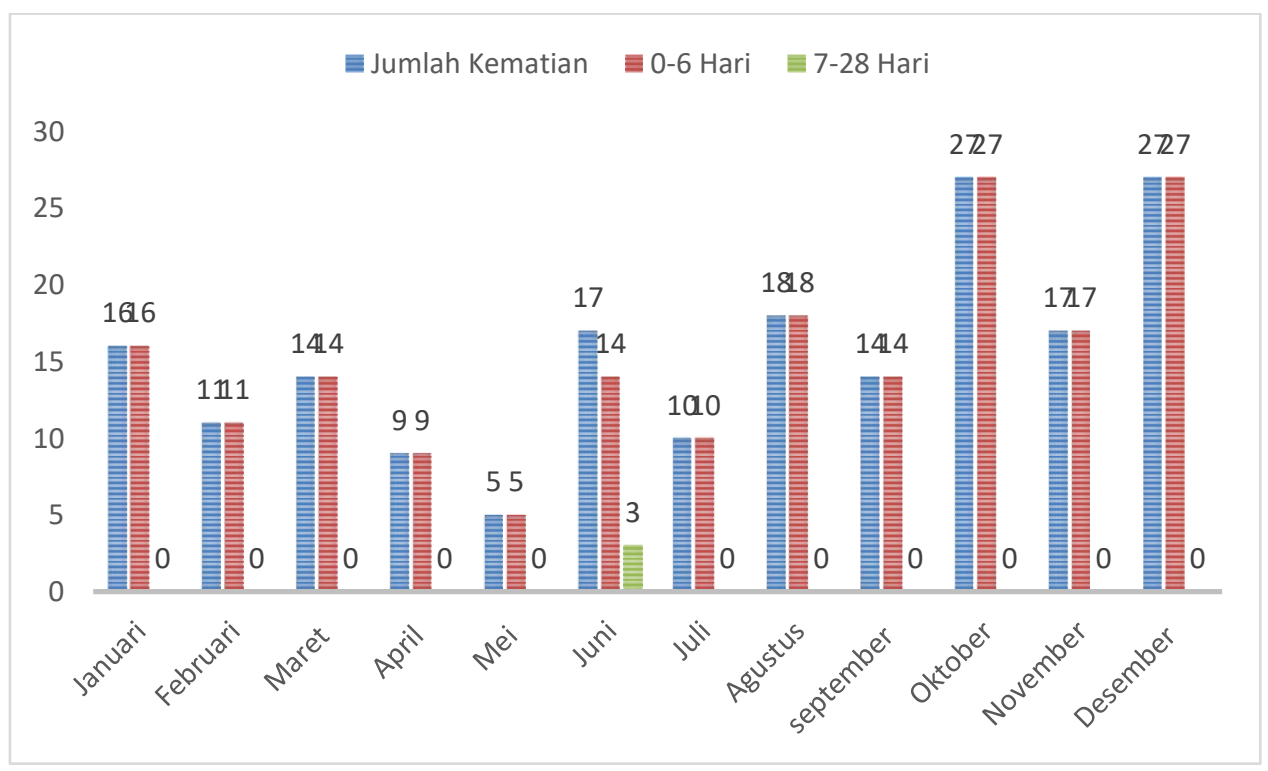

Gambar 2. Besar Kematian Bayi Berdasarkan Usia Tahun 2018

Berdasarkan gambar 3 tersebut dapat diketahui bahwa kematian bayi banyak terjadi pada jenis kelamin laki -laki sebanyak 110 bayi meninggal. Kematian bayi jenis kelamin laki laki tertinggi terjadi pada bulan Oktober tahun 2018 sebanyak 19 kematian bayi, sedangkan terendah terdapat pada bulan Mei sebanyak 5 kematian bayi. Kemudian kematian bayi dengan jenis kelamin perempuan jumlah tertinggi terdapat pada bulan Desember 2018 sebanyak 10 kematian bayi.

Karakteristik menurut jenis kelamin menunjukkan bahwa persentase perempuan mempunyai keluhan kesehatan dan mengobati sendiri dalam sebulan terakhir lebih tinggi dibandingkan laki-laki, sebaliknya untuk jenis kelamin laki-laki yang mempunyai keluhan

\footnotetext{
${ }^{10}$ Bappenas, “Republik Indonesia Pembangunan Milenium Indonesia 2010,” Bappenas (2010). 
kesehatan dan rawat jalan lebih tinggi dibandingkan dengan anak perempuan dengen persentase 0,45 persen. ${ }^{11}$

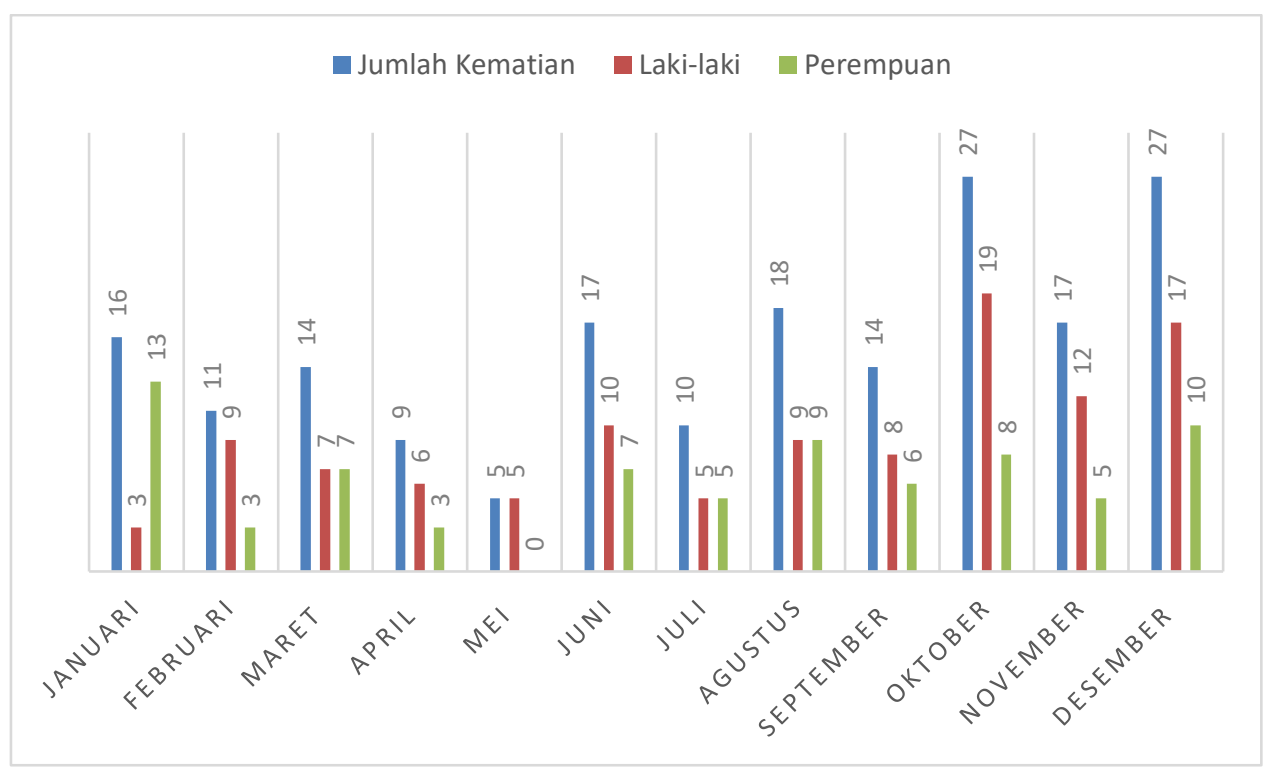

Gambar 3. Kematian Bayi per bulan Berdasarkan Jenis KelaminTahun 2018

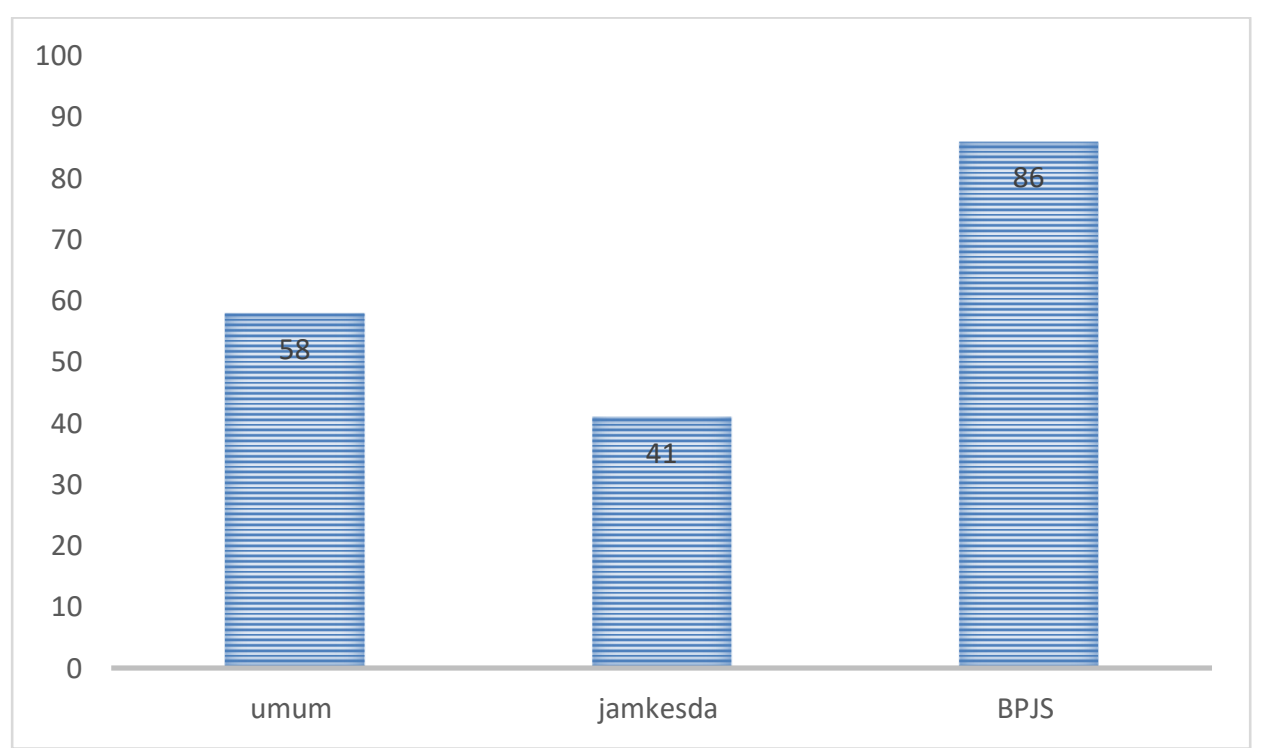

Gambar 4. Distribusi Jenis Jaminan Kesehatan pada kasus kematian bayi

Berdasarkan gambar 4 tersebut dapat diketahui bahwa jenis jaminan kesehatan yang paling banyak digunakan adalah BPJS yaitu sebanyak 86 kasus kematian bayi. Menurut undang Undang nomor 36 Tahun 2009 tentang Kesehatan disebutkan bahwa

\footnotetext{
${ }^{11}$ Badan Pusat Statistik RI, “Profil Kesehatan Ibu Dan Anak 2020,” Badan Pusat Statistik 53, no. 9 (2020): 1689-1699.
} 
setiap orang berkewajiban turut serta dalam program jaminan kesehatan sosial. Sehingga dapat diketahui bahwa sudah banyak masyarakat yang memiliki jaminan kesehatan yang dikelola oleh pemerintah yaitu BPJS untuk dapat mendapatkan fasilitas kesehatan ${ }^{12}$ Menurut Taguchi, Kawabata,Maekawa,Maruo dan Dewata, 2003 dalam Profil Kesehatan Ibu dan Anak 2020 jaminan kesehatan merupakan suatu upaya untuk menjamin ibu untu mendapatkan pelayanan kesehatan secara menyeluruh mulai dari peningkatan kesehatan(promotif), pencegahan penyakit (preventif), pengobatan (kuratif) dan pemulihan kesehatan (rehabilitatif). ${ }^{13}$ Sehingga kepemilikan jaminan kesehatan menjadi sangat penting untuk ibu dalam mengatasi kondisi ekonomi ibu yang tidak dapat mengakses ke fasilitas kesehatan karena tidak ada biaya dan jaminan kesehatan dapat digunakan untuk mendapat pelayanan kesehatan tanpa biaya.pada saat ini, jaminan kesehatan yang paling banyak dimiliki oleh ibu adalah BPJS kesehatan, baik BPJS penerima bantuan iuran (PBI) ataupun BPJS non PBI.

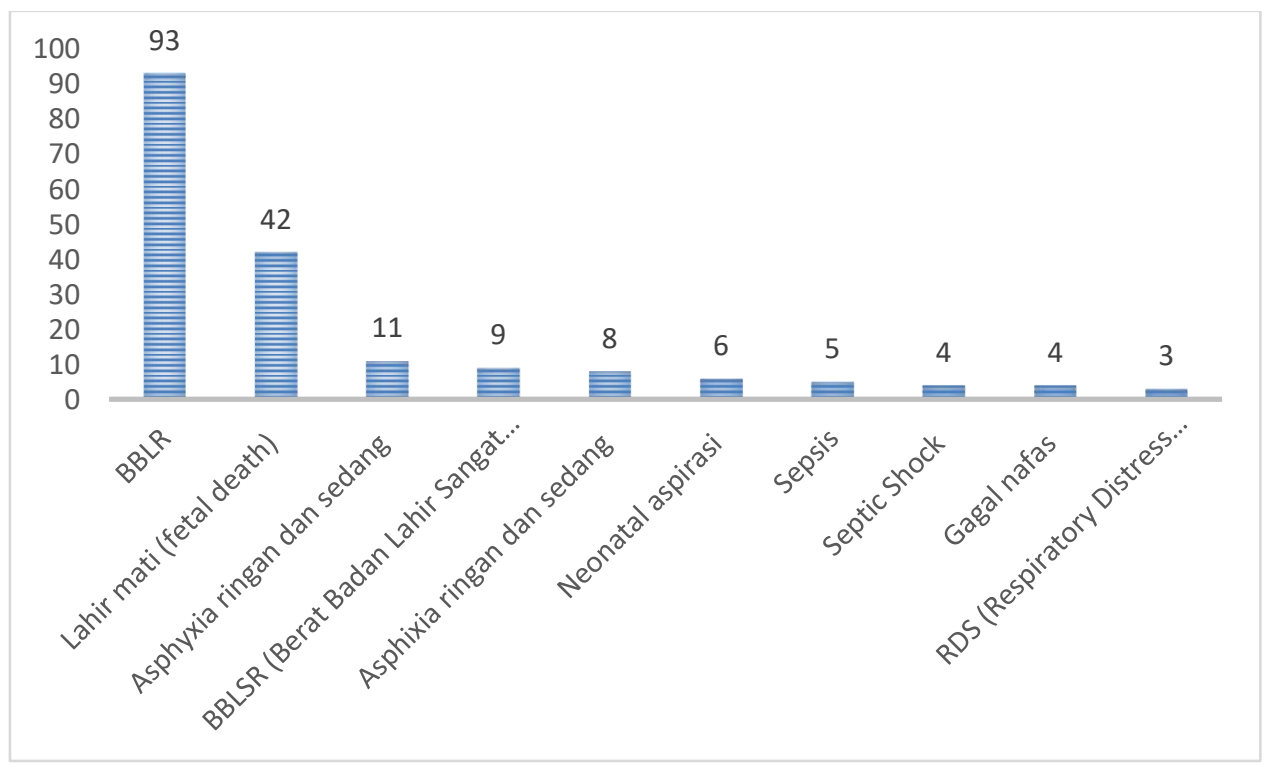

Gambar 5. Distribusi Penyebab Kematian Bayi pada tahun 2018

Berdasarkan gambar 5 tersebut dapat diketahui bahwa diagnosa tertinggi yang menyebabkan kematian bayi adalah kode P07.1 yaitu BBLR (Berat Badan Lahir Rendah) dengan jumlah 93 kasus, kode P95 yaitu lahir mati (fetal death) dengan jumlah 42, kode P21.0 yaitu asphyxia ringan dan sedang dengan jumlah 11, P07.0 yaitu BBLSR (Berat Badan Lahir Sangat Rendah) sebanyak 9, P21.1 asphixia ringan dan sedang sebanyak 8, P24.0 neonatal aspirasi sebanyak 6,dan diagnosa terendah adalah P22.0 yaitu RDS (Respiratory Distress Syndrome) sebanyak 3 kasus.

\footnotetext{
${ }^{12}$ Badan Pusat Statistik et al., "Survei Demografi Dan Kesehatan Indonesia 2012."

${ }^{13}$ Ibid.
} 
Hal ini dapat terjadi karena ibu hamil dengan konsumsi gizi yang rendah dan mengalami penyakit infeksi akan melahirkan bayi dengan berat lahir rendah (BBLR) dan atau panjang bdan bayi yang dibawah standar. Asupan gizi yang baik tidak hanya ditentukan oleh ketersediaan panga ditingkat rumah tangga tetapi juga dipengaruhi oleh pola asuh ibu yaitu pemberian kolostrum (ASI yang pertama kali keluar), Inisiasi Menyusu Dini (IMD), pemberian ASI Esklusif dan pemberian makanan pendamping ASI (MP-ASI) secara tepat ${ }^{14}$

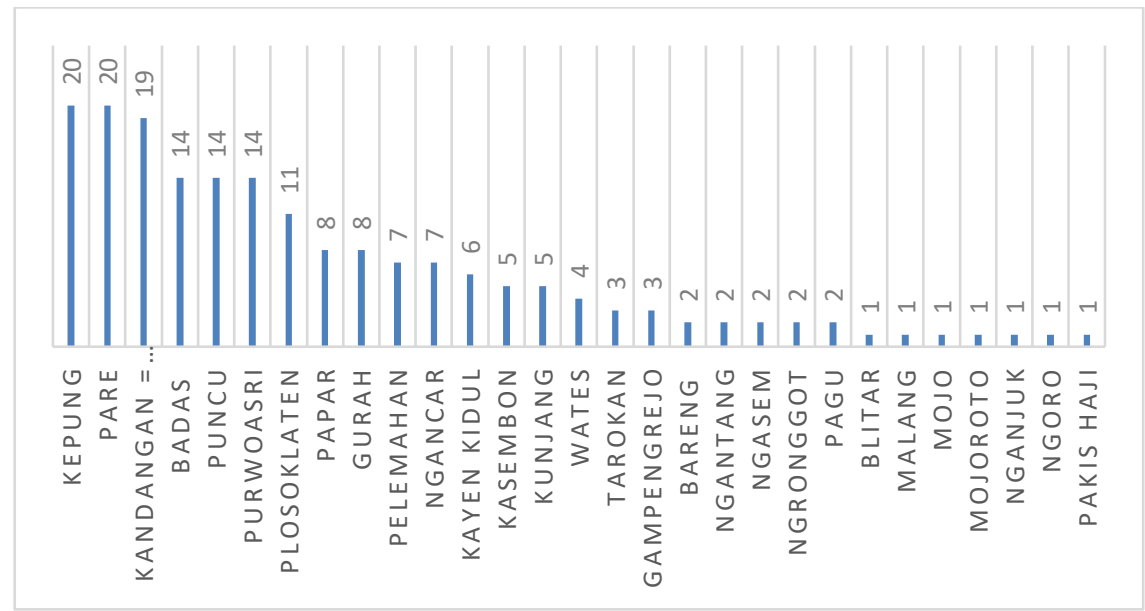

Gambar 6. Distribusi Kematian Bayi Berdasarkan Wilayah

Berdasarkan gambar 6 tersebut dapat diketahui bahwa wilayah atau tempat tinggal bayi yang meninggal di RS X Kabupaten Kediri terbanyak dari wilayah Kepung dengan 20 kasus dan Pare dengan 20 kasus.

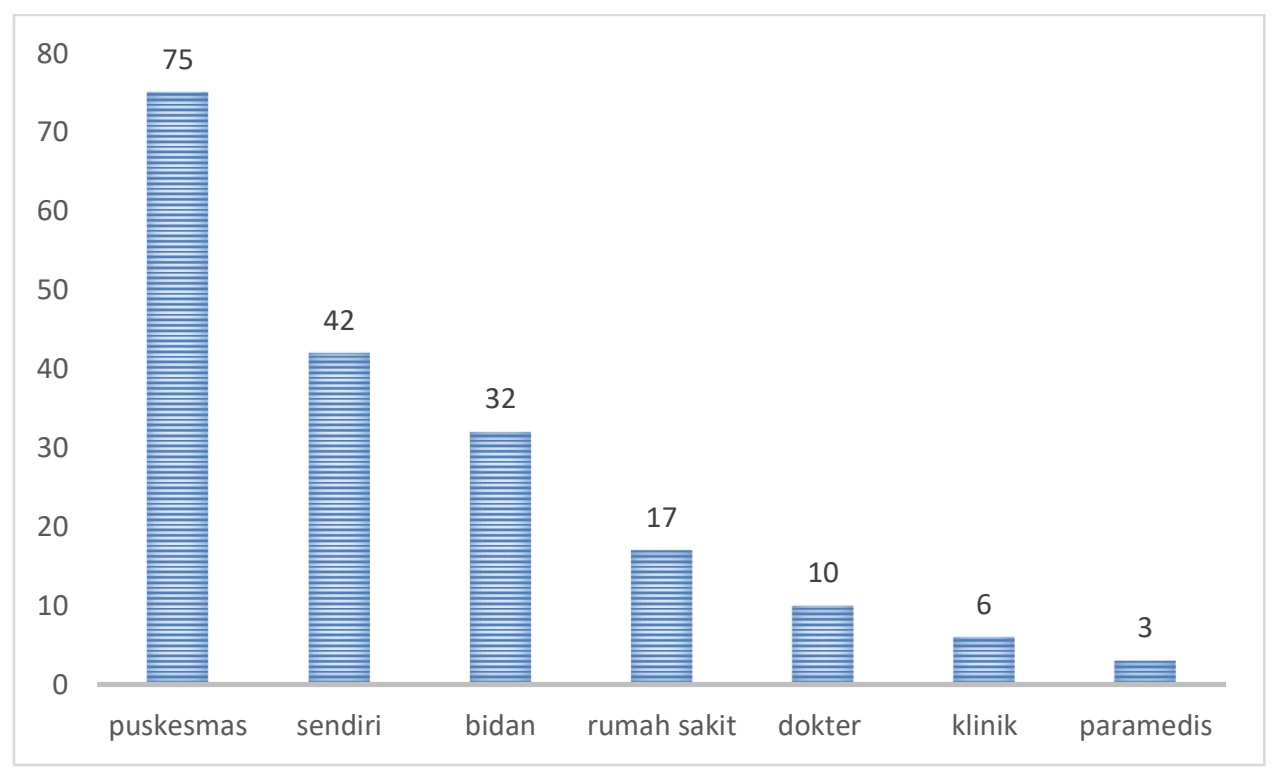

${ }^{14}$ Badan Pusat Statistik RI, “Profil Kesehatan Ibu Dan Anak 2020.”

Copyright $($ C 2020; MASOKAN, ISSN: $\quad$ (print), $\quad$ (online) | 48 
Gambar 7 Jenis Asal Rujukan dari kasus kematian bayi pada tahun 2018

Berdasarkan gambar 7 tersebut dapat diketahui bahwa jenis rujukan dari kasus kematian bayi paling banyak bersal dari puskesmas yaitu sebesar 75 kasus dan yang paling banyak berikutnya yaitu pasien datang sendiri sebanyak 42 kasus. Hal ini menunjukkan kepercayaan dan kesadaran masyarakat terhadap fasilitas pelayanan kesehatan semakin baik dan mudahnya akses pelayanan kesehatan yang menjadi dasar dari banyaknya kasus ditangani dan segera mendapatkan rujukan untuk datang ke rumah sakit. Selain itu dengan yang paling banyak rujukan berasal dari Puskesmas, menunjukkan bahwa masyarakat sudah banyak yang memiliki jaminan kesehatan yaitu BPJS dimana sebelum ke rumah sakit, maka masyarakat terlebih dahulu mendapatkan pelayanan di Puskesmas. Dari data BPS tahun 2020 menunjukkan bahwa penggunaan jaminan kesehatan baik untuk rawat jalan atau rawat inap di daerah perkotaan lebih tinggi dibandingan daerah pedesaan 15

\section{Angka Kematian Bayi/Infant Mortality Rasio (IMR) Tahun 2018 di RS X Kabupaten Kediri}

Perhitungan nilai Infant Mortality Rasio (IMR) sebagai berikut (Hatta, 2014) :

$$
\mathrm{IMR}=\frac{\text { Jumlah kematian bayi }(0-11 \text { bulan }) \text { dalam } 1 \text { tahun }}{\text { Jumlah kelahiran hidup dalam } 1 \text { tahun }} \times 1000
$$

Berdasarkan rumus perhitungan angka kematian bayi tersebut dijabarkan pada tabel berikut yang merupakan tabel yang menggambarkan bagaimana hasil perhitungan angka kematian di RS X Kabupaten Kediri tahun 2018.

Tabel 2 Angka Kematian Bayi Tahun 2014-2018 Di RSUD Kabupaten Kediri

\begin{tabular}{ccccc}
\hline No. & Tahun & $\begin{array}{c}\text { Jumlah Bayi } \\
\text { Hidup }(\boldsymbol{y})\end{array}$ & $\begin{array}{c}\text { Total Bayi } \\
\text { Mati }(\boldsymbol{x})\end{array}$ & $\begin{array}{c}\text { IMR }\left(\frac{\boldsymbol{x}}{\boldsymbol{y}} \boldsymbol{x} \mathbf{1 0 0 0}\right) \\
\mathbf{( \% o})\end{array}$ \\
\hline $\mathbf{1}$ & 2018 & 2.729 & 185 & 67,79 \\
\hline \multicolumn{2}{r}{ Total } & 2.729 & 185 & 67,79 \\
\hline
\end{tabular}

Pada tabel 2 tersebut dapat diketahui bahwa nilai IMR sebesar 67,79 menunjukkan bahwa masih jauh dari standar yang ditetapkan oleh MDGs pada tahun 2015 yaitu

\footnotetext{
${ }^{15}$ Ibid.
} 
menurunkan Angka Kematian Bayi hingga 23 per 1000 Kelahiran Hidup dan target Renstra pada tahun 2019 yaitu 24 per 1000 Kelahiran Hidup, hal ini menunjukkan jumlah kunjungan bayi yang melakukan rawat inap atau peningkatan pada jumlah kematian bayi yang masih sangat tinggi di RS X Kabupaten Kediri.

Kematian bayi menggambarkan bagaimana pemeliharaan dan kekurangan gizi pranatal dan pascanatal. Hal ini terjadi karena apabila ibu memperoleh asupan kalori dan nutrisi yang cukup dengan ditandai kenaikan berat badan ibu ketika hamil, ini dapat meningatkan berat lahir bayi dan dapat mengurangi kematian serta kesakitan bayi. Perolehan pelayanan kesehatan yang cepat pada saat hamil, tidak mengkonsumsi obat obatan, zat kimia, alkohol dan tidak merokok juga dapat membantu mengurangi kematian bayi. Selain ibu pemberian imunisasi yang tepat pada sesaatsetelah bayi lahir juga dapat mengurangi kematian bayi. ${ }^{16}$

\section{Kesimpulan}

Berdasarkan hasil penelitian, maka kesimpulan yang dapat diambil, yaitu:

1. Angka kematian bayi pada tahun 2018 sebanyak 185 kasus dari 2.729 kelahiran hidup dan kasus yang paling banyak terjadi pada $\leq 48$ Jam sebanyak 102 kasus.

2. Kematian bayi paling banyak terjadi pada bulan Januari dan Desember dan terendah pada bulan Mei dan usia terbanyak yang mengalami kematian bayi adalah umur 0-6 hari sebanyak 182 kasus.

3. Penyebab kematian bayi yang paling banyak adalah BBLR (Berat Bayi Lahir Rendah) sebanyak 93 kasus dan terendah pada RDS ( Respiratory Distress Syndrome) sebanyak 3 kasus.

4. Nilai Angka Kematian Bayi sebesar 67,79 menunjukkan bahwa masih jauh dari standar yang ditetapkan oleh MDGs pada tahun 2015 yaitu menurunkan Angka Kematian Bayi hingga 23 per 1000 Kelahiran Hidup dan target Renstra pada tahun 2019 yaitu 24 per 1000 Kelahiran Hidup

Sebaiknya nilai Angka Kematian Bayi dapat selalu dilakukan untuk dasar dalam membuat perencanaan bagi rumah sakit dalam menyediakan sarana dan prasarana yang dapat mendukung kesehatan ibu dan anak yang melakukan kunjungan ke rumah sakit utamanya perhatian penuh pada bulan Oktober dan Desember.

\section{Referensi}

Badan Pusat Statistik, Badan Koordinasi Keluarga Berencanan Nasional, Departemen Kesehatan, and Macro International. "Survei Demografi Dan Kesehatan Indonesia

\footnotetext{
${ }^{16}$ Thomas C. Timmreck, Epidemiologi "Suatu Pengantar" (EGC, 2004).
} 
2012." Sdki (2013): 16.

Badan Pusat Statistik RI. "Profil Kesehatan Ibu Dan Anak 2020." Badan Pusat Statistik 53, no. 9 (2020): 1689-1699.

Bappenas. "Republik Indonesia Pembangunan Milenium Indonesia 2010.” Bappenas (2010).

Notoatmodjo, Soekidjo. Metodologi Penelitian Kesehatan. KOTA SURABAYA - BUBUTAN, JAWA TIMUR, ID: Rineka Cipta, 2018.

Pemerintah Kabupaten Kediri, Dinas Kesehatan Kab. Kediri. "Profil Dinas Kesehatan Kabupaten Kediri" (2017).

_-_. "Profil Kesehatan Kabupaten Kediri Tahun 2016" (2016).

PP No. 87. "Peraturan Pemerintah Republik Indonesia Nomor 87 Tahun 2014 Tentang Perkembangan Kependudukan Dan Pembangunan Keluarga, Keluarga Berencana, Dan Sistem Informasi Keluarga." Salinan (2014): 1-65.

profil kesehatan indonesia. Provil Kesehatan Indonesia 2018. Vol. 1227, 2018. website: http://www.kemkes.go.id.

Sudra, Rano Indradi. Statistik Rumah Sakit. KAB. SLEMAN - SLEMAN, DI YOGYAKARTA, ID: Graha Ilmu, 2010.

Timmreck, Thomas C. Epidemiologi “Suatu Pengantar.” EGC, 2004. 